\title{
Navegar é preciso, viver também é preciso: ideias iniciais sobre a organização e a percepção de tempo de marinheiros brasileiros em navio polar
}

DOI

http://dx.doi.org/10.11606/ 2179-0892.ra.2017.141653

\section{Sarah de Barros Viana Hissa}

- Universidade Federal do Rio de Janeiro / Rio de Janeiro, RJ, Brasil

$\boldsymbol{\nabla}$ sarah.hissa@gmail.com

\section{RESUMO}

A pesquisa científica brasileira na Antártica se dá desde 1982, com apoio logístico da Marinha Brasileira. Após uma permanência relativamente breve nos navios polares, busca-se discutir como os marinheiros percebem o tempo e sua passagem. Discutiu-se a percepção do tempo a partir de três vieses: atividades desempenhadas, movimentos de retenção e protensão da consciência e algumas festividades observadas. Percebeu-se que um desejo de que o tempo passe rapidamente e que as atividades, sejam de lazer ou de trabalho, proporcionam uma sensação de passagem rápida de tempo. A lembrança de casa se faz constante, sugerindo uma presença parcial dos marinheiros naquele espaço, onde outros locais e momentos são chamados a habitar a Antártica. Neste sentido, as festas poderão significar, para os marinheiros, uma forma de intensificação do presente. 


\section{APRESENTAÇÃO: \\ PESQUISAS BRASILEIRAS NA ANTÁRTICA E APONTAMENTOS SOBRE ESTE ESTUDO'}

Desde 1982, a partir do Programa Antártico Brasileiro (Proantar), são desenvolvidas pesquisas científicas brasileiras no continente austral ${ }^{2}$. Este programa integra a participação de vários ministérios: Ministério da Ciência, Tecnologia e Inovação, do Meio Ambiente, das Relações Exteriores, das Minas e Energia e da Defesa, sendo que a Marinha Brasileira é responsável pela logística do trajeto dos pesquisadores. Isso significa transporte, provimento e segurança dos envolvidos. Quando das duas Operações Antárticas (Operantar) das quais participei (nos verões de 2010 e 2011) o Proantar atuava com, além da Estação Antártica Comandante Ferraz, dois navios polares (NPs) tripulados com praças e oficiais, o NP Ary Rongel e o NP Almirante Maximiano, ambos contando com o auxílio de helicóptero para o transporte de cargas e pessoal entre o navio e o continente austral ou ilhas subantárticas. Há um apoio integrado da Força Aérea Brasileira, através do suporte de aeronaves Hércules, em sete voos anuais, que transportam cargas e pessoas entre a Antártica e o Brasil. Os pesquisadores, provenientes de várias universidades brasileiras e internacionais em cooperação científica, conduzem, naquele local, pesquisas especialmente nos campos da geologia e biologia (Souza, 2008). A partir da participação do Laboratório de Estudos Antárticos em Ciências Humanas da Universidade Federal de Minas Cerais (Leach - UFMC ${ }^{3}$ ) no Proantar, desde 2009, são também realizadas pesquisas brasileiras na área das Humanidades, em arqueologia e antropologia (Ribeiro e Croveto, 2011; Cuimarães e Moreira, 2011; Hissa, 2011; Resende 2011; Santibáñez, 2011; Villagran e Schaefer, 2011; Zarankin et al., 2011).

É neste contexto que se deu esta pesquisa etnográfica. O objetivo da pesquisa, dado que nos encontramos no mesmo tempo tipológico (Fabian, 2013) que os pesquisados, é discorrer sobre como se dá a organização e a percepção de tempo dos marinheiros ${ }^{4}$ brasileiros a serviço na Antártica.

Para tratar este tema, pode-se dizer que o meu reconhecimento do ambiente militar se iniciou antes da minha participação na Operantar e da minha presença no continente antártico propriamente dito. É necessária, como condição obrigatória para a viagem antártica dos pesquisadores, a realização de um Treinamento Pré-Antártico (TPA). Neste TPA, são realizadas atividades de acampamento, escalada, uso de bote, prática de nós de marinheiro, uso de GPS, entre outras. Mais importante, penso eu, as várias atividades são realizadas com horário e local específicos, de maneira regrada, em equipe. Como em Leirner:

ao contrário de sociedades em que os antropólogos observam "regras implícitas", tais grupos [agentes do Estado], e os militares especialmente, têm de antemão
1 Em meio à minha pesquisa de mestrado, com concentração em arqueologia, tive a oportunidade de conviver com marinheiros brasileiros, praças e oficiais, quando estes se encontravam à serviço da Marinha Brasileira e em direção à Antártica. A dissertação versou (Hissa, 2011), no âmbito da arqueologia histórica, sobretudo sobre percepções de tempo dos marinheiroscaçadores do século XIX. No entanto, este tópico me levou, em busca de respostas alternativas e elucidativas no próprio presente, a indagar as percepções destes marinheiros atuais, em alguns pontos similares aos grupos passados, que eram meu objeto primeiro de pesquisa.

2 O Tratado Antártico (assinado em 1959), firma a pesquisa científica como o objetivo principal da presença humana atual naquele continente (ressalta-se que há, também, turismo antártico). Este processo pode também ser compreendido como "colonização científica", problematizando questões de transnacionalidade e cosmopolíticas (Ribeiro e Croveto, 2011).

3 O trabalho de pesquisadores do Leach em arqueologia antártica se iniciou com Andrés Zarankin e Maria Ximena Senatore, em 1995 , quando se envolveram em escavações na ilha Livingston (Zarankin e Senatore, 2007). A partir de 2010, novas escavações passam a ser realizadas, com apoio do Proantar, desde quando, também, estudos antropológicos passam a ser desenvolvidos, estendendo o estudo das ocupações humanas antárticas para o presente.

4 Refere-se aqui a marinheiros como um termo 
ARTIco | Sarah de Barros Viana Hissa | Navegar é preciso, viver também é preciso: ideias iniciais sobre a organização e a percepção de tempo de marinheiros brasileiros em navio polar

regras explícitas e protocolos que tanto servem de parâmetro para suas "próprias" condutas quanto para o que devem ser as "condutas dos outros" (Leirner, 2009: 32).

Penso que o TPA é um momento em que o pesquisador é exposto às normas e termos militares e, de forma análoga, os militares reconhecem quem são os pesquisadores que levarão para a Antártica e por cuja segurança se responsabilizarão5. Os marinheiros são habituados a esse ambiente e estrutura militares, dado seu treinamento prévio ${ }^{6}$, diferentemente dos pesquisadores. Apesar do TPA, estes continuam desconhecendo a maior parte dos protocolos militares, de modo que, nos NPs, algumas normas são flexibilizadas. Segue um exemplo. Leirner (2009: 42) fala do ordenamento militar do espaço, ilustrando com o fato de que o lugar que se toma à mesa das refeições respeita a hierarquia de comando. Isto também acontece nos navios polares, no que os marinheiros ainda respeitam o lugar do superior, o Capitão-de-Mar-e-Cuerra, seguido pelo imediato e demais sucessivamente, a cada lado do superior. Contudo, como esta norma não se aplica diretamente aos pesquisadores (pois não fazemos parte desta hierarquia), a regra é afrouxada para nós. Intercala-se arbitrariamente à mesa pesquisadores e oficiais? ${ }^{7}$.

Isto já nos leva a apresentar a minha presença nos navios. Durante as sete semanas que passei embarcada ${ }^{8}$ foi possível observar o desenvolvimento dos trabalhos de apoio à pesquisa e participar de algumas reuniões de logística da Marinha e de algumas festas, tanto de praças quanto de oficiais ${ }^{9}$. Além disso, ao final da segunda expedição, já no retorno ao Brasil, foram feitas entrevistas semiestruturadas com cinco pessoas da tripulação do NP Ary Rongel, das quais todos eram praças, todos participaram de forma voluntária e sem supervisão direta de oficial superior ${ }^{10}$. Nestas entrevistas, utilizei-me de um pequeno roteiro, que balizou o início das entrevistas, mas que permitiu digressões. Este roteiro foi previamente avaliado pelas autoridades do navio, de modo a subsidiar a própria decisão de autorizar as entrevistas formais que realizei com os praças ${ }^{11}$.

Entendendo que cada pesquisa apresenta sua especificidade (Feldman-Bianco, 2010), do que decorre a importância de esclarecer alguns preceitos metodológicos utilizados, aponto que a pesquisa de campo que origina este artigo aproximou-se do que Jeffrey e Troman (2004) chamam de etnografia em tempo comprimido (compressed time mode). Trata-se de uma permanência curta de tempo, na qual o pesquisador habita o local permanentemente de cerca de apenas alguns dias a um mês. Deste modo, as conversas com os habitantes são intimistas e permutadas com as rotinas cotidianas. Neste sentido, são importantes os detalhes pormenores, a criação de um contexto antropológico e o diário de campo. O resultado deste tipo de etnografia é uma fotografia, snapshot, e um recorte de um momento ou local (Jeffrey e Troman, 2004). Esta pesquisa se deu de modo similar ao descrito como genérico, popular, não a patente mais baixa da marinha (cf. Castro e Leirner, 2009).

5 Leiner (2009) fala da percepção dos pesquisados de que há uma comparabilidade simétrica entre academia e mundo militar, sob a égide de duas dimensões, a hierarquia e a disciplina. Com base nesta comparabilidade, haveria uma tentativa de estreitar laços por parte dos militares, contudo, sob seu controle. Isso é um ponto de investigação interessante, já que a presença militar-Marinha-na Antártica se fundamenta justamente na pesquisa acadêmica, mas não pôde ser explorado no âmbito desta pesquisa.

6 Segundo Leiner, isto se dá ao longo de "rituais expiatórios, treinamentos físicos e repetição constante de recursos mnemônicos, cuja função parece ser a inculcação 'naturalizada' ou a 'decoração' de princípios militares" (2009: 41). Como salienta Castro (2009), durante a construção do eu militar, ainda nos treinamentos do cadete, reforça-se a categoria do civil, como oposição identitária.

7 Seria interessante observar como a hierarquia acadêmica se comporta frente a esta hierarquia militar, mas esse tópico ficará para outro trabalho.

8 Em 2010, fiquei embarcada durante cinco semanas. Normalmente o trajeto até a Antártica demora uma semana de ida e outra de volta, somando duas semanas. Contudo, naquele ano, o navio Almte. Maximiano ficou atracado em porto no Chile, para reparo. Em 2011, fiquei embarcada duas semanas, uma em cada trajeto. 
etnografia em tempo comprimido, pois, além de se tratar de um tempo curto de campo, da participação das rotinas cotidianas, da realização de entrevistas e da produção de um recorte explícito do todo, usou-se de um tema específico que deu o foco da pesquisa, a saber, a organização do tempo e a percepção da sua passagem.

Outras etnografias de/com militares foram realizadas por meio de observação participante (cf. Castro e Lairner, 2009), como foi o caso da pesquisa de Leiner (2009), que foi sistemática entre 1992 e 1997, em períodos intermitentes. Contudo, como explicita Gilberto Velho, ao citar os trabalhos de Lévi-Strauss, Evans-Pritchard e Marcel Mauss, a duração do campo etnográfico não estaria relacionada necessária e intrinsecamente à qualidade da pesquisa realizada. Para Velho: "não há cânones nem regras rígidas em um trabalho que depende muito de sensibilidade e intuição", de modo que a qualidade dependeria de preparo teórico prévio (Velho, 1980: 14). Não obstante, como os próprios autores afirmam, este formato não necessariamente possibilita emergir grande variedade de situações empíricas (Jeffrey e Troman, 2004). Além disso, é possível que etnografias feitas em tempo comprimido ofereçam ao pesquisador pouco tempo de maturação das ideias e interpretações, tal como para o aprofundamento das relações interpessoais. Por exemplo, as entrevistas que fiz foram realizadas somente na última semana da Operantar de 2011. Elas adentraram abruptamente ao tema do tempo percebido, produzindo, sim, informações válidas, mas a etapa de campo cessou também abruptamente quando se chegou ao destino. Isso implicou na impossibilidade de esclarecer dúvidas pendentes e redirecionar a pesquisa em função dos dados obtidos. Além disso, as entrevistas não foram feitas de modo nem intensivo e nem sistemático, no sentido de que poucos marinheiros foram entrevistados formalmente e que eles não representavam todos os grupos de trabalho, conforme ficará explícito. Com isto em mente e considerando que a duração da pesquisa etnográfica dependeu da logística e cronograma da pesquisa arqueológica, aponto que as interpretações aqui oferecidas são preliminares e poderão guiar novos estudos, tal como ser desafiadas por novos dados.

Ainda assim, o tempo que passei embarcada me permitiu certa aproximação e iniciar algumas conversas sobre o tema. Em tópico relacionado, Leirner (2009) relata que ele e outros antropólogos estudando militares tiveram várias dificuldades em se aproximar do objeto de estudo, desde demoras a respostas à fuga do informante. Na breve pesquisa que realizei, não me deparei com situações deste tipo. Suponho que esta facilidade relativa de acesso ao informante poderá se relacionar, ao menos em parte, ao fato de que a presença militar-Marinha - na Antártica se fundamenta justamente na pesquisa acadêmica. Este ponto poderá ser mais bem trabalhado em pesquisas etnográficas de longo prazo nos espaços antárticos, como a de Resende (2011).

Deste modo, com base nas conversas e entrevistas, buscou-se compreender
9 Na hierarquia da Marinha Brasileira, os oficiais são patentes superiores aos praças (para mais informações, ver quadro em Castro e Leirner, 2009).

10 Quando recebia autorização para realizar as entrevistas, fui informada por oficial que a participação dos praças seria voluntária, diferentemente do relatado por Atassio (2009), que, ao pesquisar praças do exército, se deparou com a convocação por ordem superior. Além disso, Atassio também entrevistou praças, contudo, com a presença de sargentos nas reuniões.

11 Isto lembra o que Leiner (2009) chama de "inversão do fluxo de informação entre antropólogo e informante". $O$ autor aponta que 0 militar, dada sua atitude de vigilância e precaução em relação à informação, busca o conhecimento do antropólogo, antes da sua pesquisa. 
a organização e a percepção de tempo na Antártica por meio de três vieses: das atividades desempenhadas (pautadas no tempo absoluto dos calendários e na oposição entre trabalho e lazer), do movimento da consciência a outros momentos que não o presente (rememoração e planejamento), e, por fim, das festividades como momentos de sociabilidade e intensificação do presente.

O próximo segmento deste texto será, então, dedicado a explicitar algo de como as atividades são organizadas na Antártica. Sem objetivar um detalhamento do cronograma anual da Operantar ou o cronograma de trabalho de cada grupo de serviço, apontarei, com base nas falas dos entrevistados, percepções acerca da prioridade do trabalho sobre o tempo livre na organização do tempo diário, discutindo tanto a relação entre o tipo de trabalho que se desempenha e possíveis diferenças de percepção de tempo, como a relação entre o local onde o navio está situado com as atividades específicas e suas possíveis percepções de tempo. O segmento do texto seguinte a esse discutirá movimentos da consciência no presente, de lembrança e planejamento, ressaltando a importância de outros tempos no tempo presente antártico (incluindo sentimentos de saudade e contato constante com o presente das famílias no Brasil), que deriva do caráter temporário da presença na Antártica. Neste ponto, a especificidade da Antártica fica mais marcada. As festividades antárticas são apontadas, ao final, como um possível viés de compreensão da relação das pessoas como o tempo presente antártico, no que, ao intensificar a sociabilidade, preenchem o agora atual. Como a pesquisa é preliminar, ao final do texto, algumas questões pouco elaboradas são evidenciadas e são apontadas possíveis direções futuras da pesquisa.

\section{E QUE O TEMPO PASSE RÁPIDO: OS PRAÇAS, SUAS ATIVIDADES E A PERCEPÇÃO DO TEMPO QUE TRANSCORRE}

A atuação do Proantar se dá a partir de planejamentos anuais, levando em consideração o verão austral, o que inclusive marca o número sequencial de cada Operação Antártica, com a realização da Operantar I datando de 1982. No plano anual, os NPs permanecem na função entre os meses de outubro e abril' ${ }^{12}$. Essa organização anual, de difícil planejamento e constantes ajustes, estrutura e ordena todas as atividades logísticas, equipamento, espaços e pessoal em um cronograma, de forma a relacionar cada atividade a um pessoal e equipamento, situando-os em um momento do ano e em dado espaço. Por exemplo, a tripulação do NP Ary Rongel buscará os pesquisadores de dado grupo científico no porto de Punta Arenas no dia $1^{\circ}$ de janeiro, após levantar carga no Rio de Janeiro. Os projetos de pesquisa devem entregar suas solicitações obedecendo ao calendário pré-fixado. Há possibilidade de alteração nas atividades e demandas para a Operação Antártica, mediante análise, contudo alerta-se que os prazos para entrega dos documentos

12 Na Operantar XXXIII (2014-2015), os NPs Ary Rongel e Almirante Maximiano desatracaram da Base Naval do Rio de Janeiro nos dias 06 e 11 de outubro, regressando em 10 e 14 de abril de 2015. 
requeridos são improrrogáveis e o não recebimento destes poderá implicar na exclusão das atividades do projeto da Operação Antártica em questão.

Como não poderia deixar de ser, a presença militar na Antártica é pautada no tempo absoluto dos calendários ${ }^{13}$, visando sincronizar as várias pessoas e instituições envolvidas, financiamentos, equipamentos e víveres, buscando rigidez e eficiência. Neste sentido, o tempo absoluto necessariamente passa-ou se sente passar-ao contrário de alguns tempos concebidos como imóveis. Neste ponto nos remetemos ao tempo ecológico dos Nuer (Evans-Pritchard, 1999). O autor pensa o tempo entre os Nuer a partir da divisão deste em tempo estrutural (referente a um macrocosmos e uma longa duração, do ciclo da vida humana ao longo das gerações) e o tempo ecológico (referente a um microcosmos e aos ciclos diários e anuais). $O$ tempo estrutural é imóvel, enquanto o tempo ecológico transcorre (Cell, 2014). A similaridade do tempo do qual falamos aqui é com o tempo ecológico, que transcorre, a partir das atividades anuais (da organização da Operantar) e diárias (do espaço militar, da dicotomia moderna entre tempo de trabalho e tempo livre). Penso o caráter militar da ordenação temporal entre os marinheiros na Antártica como uma organização social, restrita, disciplinada e hierarquizada, porém de um tempo que passa (não é estrutural no sentido sincrônico, imóvel).

Sobretudo, pode-se dizer que, mais que a necessidade de sincronização, a pontualidade frente o tempo absoluto parece ser um valor especial, em consonância com os valores de formalidade, de oficialidade e da autoridade da hierarquia e da disciplina. É um conjunto de ideais, que se expressam em harmonia. Tal como em Castro (1990: 136), com base em Foucault e Weber, sobre os militares na Academia: "Acompanhando o regime de internato encontramos horários para as atividades cada vez mais meticulosas, prescrições disciplinares precisas, revistas, formaturas, numa palavra, disciplina".

Este conjunto de valores está expresso nos espaços dos navios e na organização do cotidiano diário destes. O espaço é categorizado por tipo de atividade e por diferenciação de acesso: camarotes, cozinhas, praça d'armas, rancho ${ }^{14}$ dos sargentos, rancho dos praças (esses três últimos, locais de alimentação e lazer, divididos conforme hierarquia militar), academia de ginástica, escritórios e salas de computadores, laboratórios de pesquisa, galpões de armazenagem, casa de máquinas, decks, passadiço (ponte de comando). Todos esses espaços, de uso coletivo (ainda que categorizado), inspiram a impessoalidade, disciplina e a oficialidade típicas de um escritório propriamente militar. Mesmo os camarotes, espaços supostamente pessoais, devem ser mantidos de forma tal a inspirarem um ideal coletivo de ordem e eficiência. A pontualidade, no espaço do navio, se faz presente nos regulares apitos que soam em alto volume, em um rádio que transmite para todo o navio, anunciando, além do despertar da tripulação e os horários de alimentação coletiva, a entrada de cada grupo de serviço ${ }^{15}$, conforme
13 Desde o advento da industrialização, a intensificação do urbano e do comércio e a secularização e cientificização do pensamento, processos referentes à construção da modernidade, o tempo é concebido principalmente como absoluto e não-humano (Fabian, 2013; Le Goff, 2005; Linder, 1970; Piettre, 1997; Schôpke, 2009; Valtonen, 2004; Weber, 2001)

14 Denomina-se ranchoo alimento (almoço e jantar) e o local onde se dá a alimentação coletiva.

15 Entre a tripulação, do capitão aos cabos (patente mais baixa a bordo), há também um médico, um dentista e um capelão. Outras atividades são divididas entre os praças: garçom, cozinheiro, eletricista, carpinteiro, encanador, programador de rede, mecânico, operador de máquinas, dentre outras. 


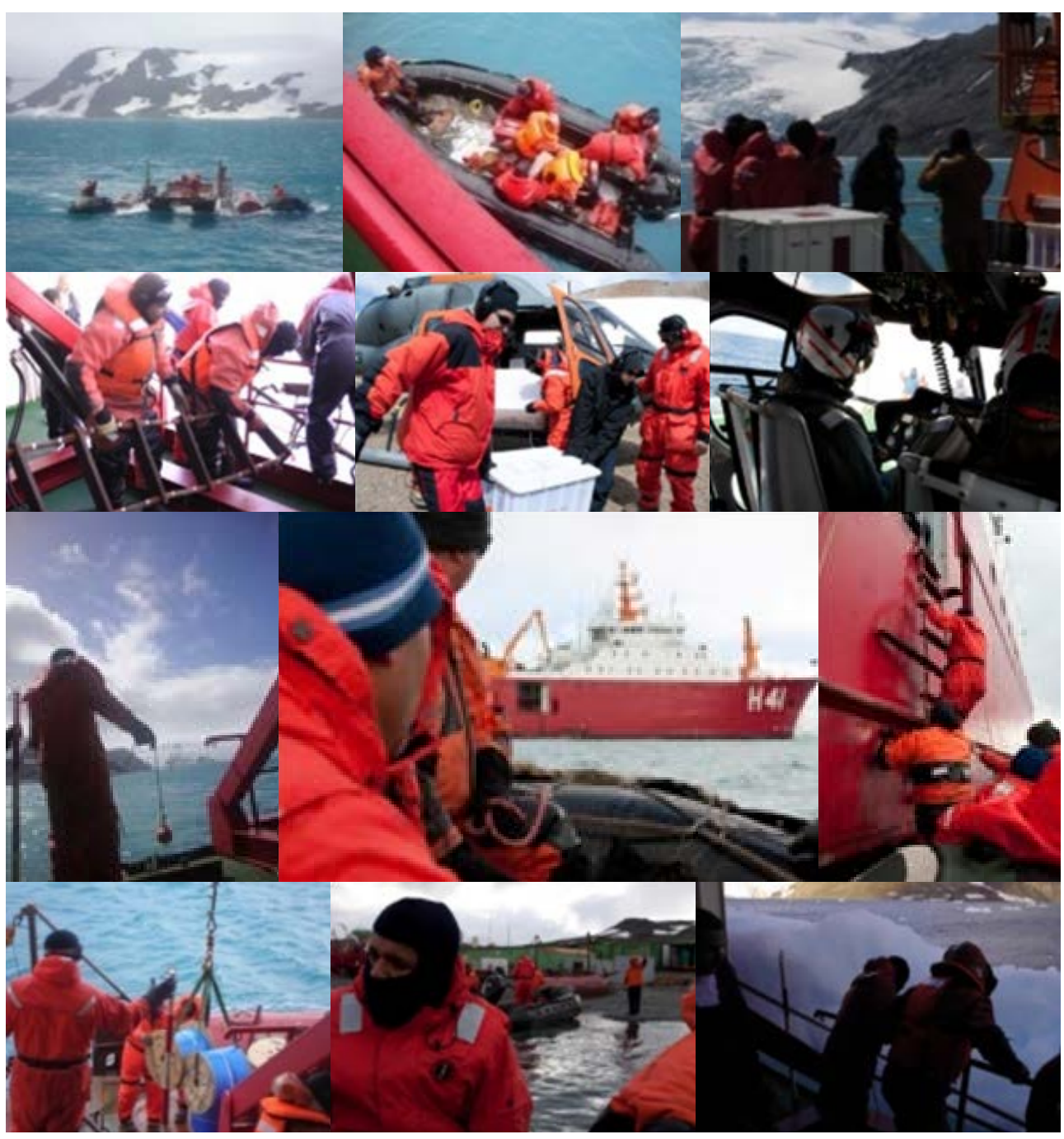

uma escala pré-estabelecida. Um marinheiro, pertencente ao grupo da avaria (ou seja, grupo de plantão, acionado quando algum equipamento apresenta problemas), relata a preeminência dos horários preestabelecidos da alimentação coletiva (café-da-manhã, almoço e jantar) e do serviço: "Cumprir horário é só o de serviço e da hora do rancho, que temos que levantar para comer. Só isso", diz o marinheiro.

Subjaz a este ordenamento diário dos marinheiros, não somente a organização militar disciplinar do espaço e do tempo, que implica a rigidez de horários de serviço e alimentação, mas também, conforme se pretende evidenciar nas falas dos marinheiros, a dicotomia ocidental contemporânea entre tempo dedicado ao trabalho e o tempo livre.

O tempo livre pode ser compreendido como ausência de trabalho ou como "tempo que alguém poderá fazer o que quiser"16 (Valtonen, 2004), tal como é compreendido na sua relação com noções de bem-estar (Magnani, 1994, 2003; Cross, 1984). A questão do lazer ${ }^{17}$, como uma atividade a ser fruída ou desempenhada no tempo livre, surge dentro do universo do trabalho e em oposição a ele (Magnani, 1994, 2003). Valtonen (2004) explicita como "there is a time to earn and a time to consume", e

\section{Figura 1}

Espaços antárticos em atividade. Foto: Leach/UFMG.
16 Ou pensar o que quiser, referindo-se ao fato de que se espera determinados pensamentos ao tempo livre (Valtonen, 2004). Por outro lado, Paul Van Dijk (2002) apresenta um questionamento que vai além deste texto, que envolve a própria existência do tempo livre. Para o autor, este é uma ilusão.

17 Este pode ser classificado como lazer sério ou casual (fazer nada ou descansar), esse tido como atividades passivas (Stebbings, 1982; 2001). 
o consumo sendo compreendido como consumo de objetos tanto quanto de lazer.

Neste ponto, cabe fazer uma breve digressão. Observa-se que a atuação da Operantar na Antártica abarca as festividades de final de ano. Valtonen chama atenção para a possibilidade em se obter prazer no trabalho, a partir de noções de satisfação profissional e estímulo pelos desafios suscitados pelo trabalho ${ }^{18}$. Contudo, Valtonen aponta que há certas ocasiões em que desmanchar a fronteira entre estes dois tempos é menos aceitável, como é o caso do sono e das celebrações de renovação da vida, como é o caso de casamentos, funerais ou natais. Isto é particularmente interessante para este caso, já que a Operantar toma justamente o final do ano, levando os marinheiros e pesquisadores para uma condição de trabalho intenso e longe da família e das celebrações de natal e réveillon. A sazonalidade - verão austral-marca a organização anual da Operantar, uma vez que várias pesquisas são realizadas somente nesta estação do ano. Trata-se da preponderância do trabalho sobre as festividades de fim de ano.

As atividades diárias dos marinheiros parecem pautar-se fortemente nesta dicotomia. Exemplifico com um relato. Um marinheiro fala da intensidade do trabalho e da dicotomia entre tempo de trabalho e de lazer, apontando também para a sensação de passar o tempo mais rápido quanto mais atividades de trabalho se tem:

Quanto mais trabalho eu tiver, melhor para mim. Mais rápido passa o dia. Você ficar à toa, não tem como. Lazer é complicado porque o navio é pequeno. Mas tem um monte. Eu não gosto de ler, assistir filme só se os outros pegarem. Eu nem pego, preguiça. DVD ou videogame. Só quando ninguém está assistindo DVD ou usando a TV. Só jogo quando os outros estiverem jogando. Computador, aísim, estou aqui sempre. Já estava aqui, vendo as fotos da nossa viagem.

Ao final do relato abaixo também se aponta na direção da relação dicotômica entre tempo de trabalho e de lazer:

Basicamente é serviço, beliche. Beliche, dorme e serviço. Come e dorme. Beliche e serviço. Esempre tem alguma coisa para fazer. Sempre. Como no dia do último churrasco, eu fiquei no apoio. Eu nem fui porque eu fiquei lá embaixo, na bomba. Porque a bomba que faz o vácuo no sistema deu problema. Tivemos que arrancá-la. Todo o sistema parou. O pessoal achou que tinha queimado as duas bombas, mas tinha queimado uma. Demorou uma hora isso daí. Aí trocamos. Foi mais ou menos uns dois dias. Aí ficamos um dia sem almoçar. Quando acontece temos que dar o sangue. Se eu parar para comer churrasco não faço mais nada. Eu prefiro trabalhar e depois lazer. 
Voltando à analogia com os Nuer, "são as próprias a tividades, notadamente as de tipo econômico, que constituem as bases do sistema e fornecem a maioria de suas unidadese notações, e a passagem do tempo é percebida na relação que uma atividade mantém com as outras" (Evans-Pritchard, 1978: 115). Este trecho é particularmente interessante para o estudo em tela, no que associa a percepção de passagem de tempo com as atividades desempenhadas. No caso dos marinheiros, penso que as atividades não são de cunho propriamente econômicos, no sentido Nuer, mas são as funções que cada patente e grupo de atividades desempenha. Mais interessante para esse caso é a possibilidade de se considerar as unidades primordiais de tempo como os períodos de serviço e de tempo livre, a partir das quais se compreende o tempo que transcorre. Outros eventos ordenados do dia, como as refeições, também poderão ser compreendidos desta forma.

Além da dicotomia entre lazer e trabalho, pode-se pensar a organização do dia dos marinheiros embarcados por meio das atividades exercidas no navio, considerando o tipo específico de serviço que se desempenha.

O funcionamento do navio se desdobra em várias tarefas distintas, distribuídas pela tripulação. Deste modo, as atividades desempenhadas não são as mesmas para todas as pessoas, em função das hierarquias militares, da divisão de pessoal em grupos de serviço, de aptidões e preferências pessoais e da especialização do trabalho. O último relato transcrito faz menção também a como a sua função específica, a do reparo (grupo da avaria), que, ao denotar plantão, implica também na priorização imediata do trabalho, nos momentos em que este reclama da presença (os acidentes e imprevistos), e restrição de determinadas atividades. Isso significa movimentos de monotonia e resposta imediata a uma contingência.

Outro relato de um marinheiro do grupo da avaria vai nessa mesma direção do relato supramencionado, sugerindo que o ritmo pessoal de trabalho não muda somente de acordo com a escala, que o inclui ou não, mas é sujeita a situações imprevisíveis e emergenciais:

Aqui é variado. Depende do serviço, porque estou no serviço 2 por 1. Agora, está circulando porque estamos atravessando o Drake e os mergulhões entram. Numa escala de patrulha. Aí, basicamente eu levanto na hora que eu quero, quando não estou de serviço. A menos que haja a lguma emergência, me chamarem para algum trabalho, algum problema que der.

Mas a imprevisibilidade das situações emergenciais no grupo da avaria é permeada pela sensação de que o tempo é repetitivo:

Para mim é repetitivo. Todo dia levanto, tomo café. Entro de serviço. Corro e vejo 
a temperatura. É difícil ter uma avaria como essa que aconteceu da bomba. Muito difícil, uma vez só a té agora. Quase nada novo (...).

Já para um garçom, o trabalho se repete porque gira em função das horas dos ranchos. O trabalho é intenso e relativamente homogêneo ao longo do dia, com as alimentações e funções circundantes em horários pré-determinados e previsíveis. "Não tem momento do dia que você se sente de folga, levanta cinco e meia e vai deitar dez e meia", diz o marinheiro. Segundo ele, as atividades diárias são organizadas mais em função das horas.

Pode-se pensar que a pressão de tempo da qual fala Margareth Mead na sua etnologia dos gregos (1953) ocupa todo o dia dos marinheiros que servem no grupo do rancho, mas apenas nos momentos de urgência dos marinheiros do grupo da avaria.

Os marinheiros do grupo da avaria parecem experimentar um tempo ocioso, repetitivo, livre e lento, a julgar pelos relatos transcritos acima, nos quais o entrevistado narra que ele acorda na hora que quer, a menos que ocorra alguma urgência. É o imediatismo e imprevisibilidade da urgência que determina o ritmo do trabalho deste grupo, não as horas do dia.

Até agora discutimos como o tempo dos marinheiros antárticos é organizado anual e diariamente, em função das atividades. O cronograma e planejamento que antecede a presença na Antártica a rege, no sentido em que a determina sazonalmente. As atividades cotidianas dos marinheiros, enquanto necessárias à função de apoio à pesquisa antártica, são reguladas em ritmo militar, que não é só o invólucro naval, mas também é rígido e formal. É a disciplina do tempo, com base na ordenação absoluta. Por outro lado, "trabalho antes do lazer" é o lema - e o tempo destinado ao serviço toma a maior parte do dia dos marinheiros ou rege qual o tempo livre destinado ao lazer. Além disso, as diferentes atividades parecem fortemente apresentar ritmos diferentes, de monotonia e imediatismo, no caso do grupo da avaria, e de intensidade e regularidade, no caso do grupo do rancho. As falas dos entrevistados parecem apontar que o grupo da avaria, por permanecer de sobreaviso em plantão, sem atividades demandadas frequentes e intensas, não pauta seu tempo através da medição horária do dia, enquanto o grupo do rancho, por terem atividades demandadas frequentes e com demanda forte por pontualidade. Dito isso, também parece possível dizer que, quanto mais atividades se desempenha, mais rápido se sente o tempo passar (essa sensação dos marinheiros aparecerá novamente em outros relatos adiante). É uma proposição simples, com a qual talvez tenhamos nos deparado nas nossas próprias vidas. Contudo, isso apresenta papel específico na Antártica, no que se parece desejar que o tempo "passe mais rápido", para que esta etapa se "finde logo". 
A viagem à Antártica parece ser, no caso dos marinheiros entrevistados, uma fase; um momento passageiro da vida ${ }^{19}$. Nem se fosse permitido pela Marinha, fariam dela um meio ininterrupto de vida. Sentem os cinco a seis meses da Operantar como extensos, em comparação com o serviço a bordo de outros navios. Um marinheiro em particular comemorava o tempo que já havia sido percorrido e que já se encontra mais perto do retorno: "Ainda bem que já está na metade", disse. Em outra fala, o parâmetro temporal é o fim do trajeto e o marco do destino final:

\begin{abstract}
Nada. Só vejo quando tem trabalho, quando tem serviço, a hora de entrar na internet. Quando tem internet. Fico ali de bobeira no Badoo. E pronto. Mais nada. Nem olho para o dia mais. Às vezes eu me perco, nem sei que dia é. Tem que olhar o calendário. Acho que o pessoal se liga só numa coisa: a cada semana que passa, diminui uma. Faltam 11.11 semanas.
\end{abstract}

Novamente, a sensação que os marinheiros transmitem, quando questionados acerca da permanência na Antártica, é a de que desejam que o tempo transcorra rapidamente, que a viagem acabe e possam retornar à família. $\mathrm{O}$ anseio pelo fim da viagem passa pelo fato de que o período que se passa na Antártica se trata de um período destacado do restante da vida. Isto evoca o caráter temporário da presença humana na Antártica, que marca, também, a presença na Antártica dos caçadores de mamíferos marinhos do século XIX ${ }^{20}$ e dos turistas antárticos no presente. É neste sentido que isto implica em uma presença parcial naquele espaço, onde outros locais são chamados a habitar a Antártica.

Os relatos levantaram também outra questão, referente às atividades desempenhadas, as águas nas quais o navio se encontra e a velocidade que se sente o tempo passar. Apesar de ser possível esquecer-nos disso após muitos dias embarcados, talvez dada a sua estrutura sólida interna, o navio é um espaço móvel. Não está fadado às mesmas vizinhanças, mas seu meio circundante é variável. Isso permite mudanças nas vivências pessoais a bordo. O próprio ritmo do navio acompanha a sua localidade no planeta e as atividades que cada uma delas requer ou proporciona: no Brasil, em movimento, atracado em algum porto, fundeado em águas antárticas. Algumas falas dos pesquisados sugerem como isso poderá se dar:

Aqui [no navio em movimento] o tempo passa rápido. Passa rápido porque eu estou sempre trabal hando. Fazendo alguma coisa, aqui e ali. Filme, trabalho, faxina. Mas no porto passa muito mais rápido. Tinha que ter mais porto. Se tivesse mais porto, a viagem passava mais rápido e seria mais tranquilo. Mas aqui, passa rápido também. Está passando rápido. Não está demorando não, está tranquilo.
19 Observa-se que esta poderá ser uma perspectiva parcial entre os marinheiros. É possível que, se ampliado o tempo de pesquisa de campo, outras formas de lidar com a viagem poderiam ser reveladas

20 Os caçadores revelam também anseio pelo fim da viagem, nos seguintes trechos de diários de bordo: "But with the hopes of a Short Voyage, We set all sail" (Com esperança de uma viagem curta, içamos velas). Ou ainda, "So Ends this day with Sweet Fealings of Home" (Então se finda este dia, em doce saudade de casa) (Verril, 1916: 92). 
Passa muito mais rápido, estar em Punta Arenas. Passa mais rápido. É muito bom. Ficamos aqui uns 20 dias quando a aeronave quebrou. Passou voando. Muito Kamikase, Maderos.

Tudo muda, quando chegamos na Antártica, principalmente na Estação. Mais atenção com limpeza, não deixar cair nada no mar. A gente fica muito mais ativo, mais atento (...). Muito trabalho, corre aqui, corre ali, por causa da carga.

As três falas transcritas sugerem que o navio em trânsito é quando o tempo passa mais devagar. Há muitas atividades a se realizar, porém, não tantas quanto na Antártica ou no porto. Nestes dois lugares, o tempo passa mais rápido, há mais atividades. Sobre o tempo que se passa fundeado, sem poder atracar e descer em terra, um marinheiro relata: Isso causa ansiedade e vontade de passear e espairecer.

Em um relato já transcrito, remeteu-se à intensidade de atividades de trabalho nos portos e na Antártica. Contudo, também se remete a atividades de lazer quando em algum porto. Nessas cidades portuárias, os momentos de folga proporcionam liberdade de movimento e de escolher atividade, espaço, companhia, alimentação. Kamikase e Maderos são bares noturnos em Punta Arenas, muito frequentados pelos praças e oficiais fora de serviço. Os marinheiros em geral, quando em portos, como em Punta Arenas, Puerto Williams, Talcahuano ou Val Paraiso, buscam sair do navio e socializarem com os moradores locais.

É possível relacionar também a localização do navio e as atividades de cada grupo. Esclareço com um único exemplo curto. As atividades do grupo do rancho, em parte, são as mesmas desempenhadas em águas antárticas ou águas brasileiras, já que se trabalha servindo mesas, dentro dos mesmos espaços fechados, nos mesmos horários. O trabalho é interno ao navio e se relaciona a atividade cotidiana básica, a alimentação. Contudo, quando atracados em algum porto, estas são ampliadas, já que têm que receber os suprimentos adquiridos.

Um último ponto a se ressaltar é o de que não se percebeu, durante as conversas com os marinheiros, a sensação de que o tempo é escasso, no sentido de Linder (1970). De forma análoga, Cross (1984) pensa que é útil pensar a alocação sociocultural de tempo em atividades em termos da economia de tempo. A única fala que vai neste sentido foi uma já transcrita de um marinheiro que trabalha no grupo do rancho e que se vê sem tempo de lazer. Evidentemente, pesquisa adicional poderá revelar novas impressões. Contudo, aponta-se, como hipótese, que isto poderá se relacionar a um esvaziamento de atividades necessárias ou desejadas no presente.

Sugeriu-se que, quanto mais atividades, de serviço ou de lazer, se desempenha, sente-se o tempo passar mais rápido. Importa notar que, nas conversas e nos trechos aqui transcritos, há um retorno recorrente à ideia de se passar o 
tempo rapidamente. Neste sentido, volta-se a Valtonen (2004). Ela aponta a frequente compreensão contemporânea do trabalho como algo não apreciado. No caso dos marinheiros, a caracterização do trabalho parece oscilar entre algo bom (no que faz o tempo correr mais rapidamente), porém ruim, no que, dada a natureza do trabalho antártico, os afasta espacialmente de suas casas, família e do fluxo de tempo em um mesmo local.

\section{SAUDADE DE CASA: O “RETORNO" AO PRESENTE DA FAMÍLIA}

Durante as conversas com os marinheiros embarcados, estes fizeram algumas menções à expectativa que se tinha da viagem e aos planos para o retorno ao Brasil. Estes dois pontos-expectativa e planejamento-referem-se a tempos distintos do que o presente antártico: antes e depois da viagem:

la ser um sofrimento, isso eu já tinha certeza, porque eu já viajei 25 dias. É triste. Ainda mais aqui que tinha quatro ou cinco portos. E tempo, cinco meses e pouco. Horrível. Ficar na água 45, 50 dias. Aí quando pensei, “Meu Deus do céu, eu vou ter que aguentar". Mas está tranquilo.

Quero viajar para a casa da minha mãe, que tem dois anos que não vejo. Eu, mulher e os filhos. Comprar um carrinho com o dinheiro daqui e pegar estrada e viajar.

Estas duas falas apontam os movimentos que ocorrem na consciência entre passado e futuro. Para Husserl ${ }^{21}$ (1973), o "tempo imanente", objeto da fenomenologia, se vale de noções de passado, presente e futuro, através da memória, do agora e das expectativas. É nesse sentido que Husserl se torna de interesse para o tema aqui em discussão. O agora, ponto de referência para os outros objetos temporais, não é simplesmente um divisor de momentos, um imediatamente anterior e outro imediatamente posterior, mas é, também, um momento em si mesmo. Este momento presente se apresenta sempre pontual e inovador, enquanto os vários "agoras" que o circundam devem ser sempre referenciados entre si, são compreendidos pelo antes e depois, pelo simultâneo ou o subsequente. Neste sentido, "[e]very act of memory contains intentions of expectation whose fulfillment lead up to the present" (Husserl, 1973: 76). Trata-se de uma constante coexistência de tempos comumente distanciados no tempo linear. Essa contínua referência multitemporal da consciência constitui o que Husserl chama de retenções e protensões, que são apropriações de tempo-respectivamente, anterior e posterior-associados ao tempo pontual original. Esses elementos de como se percebe o tempo, retenções e protensões funcionam para construir uma noção de continuidade: "Through these retentions and protentions, the actual

21 Gell considera a teoria de Husserl e sua consciência interna do tempo "a explicação mais cuidadosa e mais complexa do tempo subjetivo disponível, mesmo depois de todos esses anos" (Gell, 2014: 207). Husserl trata do tempo da série $A$ (distinção oferecida em Gell, com base em McTaggart), focando em uma memória de curto prazo, das relações entre passado, presente e futuro, mantendo-os de forma dinâmica, na medida em que, a partir dos agoras sequenciais, cada momento passado ou presente é visto de forma diferente, de acordo com a distância e perspectiva. 
content of the stream is joined together" (Husserl, 1973: 111). A tese de Husserl é a de que esta é uma forma necessária de vinculação entre vividos e é medido pelo fluxo do vivido: uma unidade finita e eterna, na qual um agora é continuamente substituído e precedido por outros (Husserl, 2006: 185).

As falas transcritas no início desta seção vão ao encontro da tese de Husserl, no que se mesclam memória e expectativa no presente. Outras falas que se seguirão também manifestam isso. Contudo, a maior parte das falas dos marinheiros, quando interrogados acerca do tempo que passam na Antártica, evoca menos os momentos de retenção e de protensão dos quais participaram (ou participarão) diretamente (como memórias de eventos específicos com a família ou projeções de viagens ou passeios específicos). Parecem evocar mais o presente da família localizada no Brasil e um sentimento genérico de saudade de casa e dos familiares:

É uma aventura fazer essa viagem. É boa. Até agora está sendo tranquila, está sendo boa. Mas a saudade é o que mais dói. Acho que a família tem que ficar perto. Principalmente para nós homens, é muito complicado. (...) É muito gratificante ver seu filho crescer. As viagens têm que ser mais curtas. Ou teria que ser bem melhor remunerado do que é agora. Porque se for pelo dinheiro não. Acho que o prazer de conhecer a Antártica é melhor que o dinheiro. Mas eu estou aqui é pelo dinheiro.

Por telefone, todos os dias, uns 20 minutos. Agora que nós estamos sem internet e sem telefone, tem três dias que eu não falo com eles. Ela nem sabe onde que eu estou, o que eu estou fazendo. Mas são só três dias. Todo o dia que eu falo com ela; é como se eu recarregasse a minha bateria.

Essa foi a minha primeira e a última. Porque eu não gosto de viajar. Saudade da família, dos filhos. É isso mesmo, não pretendo viajar não. Nunca mais.

Eu mal, mal pisei na Estação, pisei uma vez. Achei muito bonita. Escorreguei na neve só. Isso daí tem que fazer, não é? Fiz um coração lá. Para a Dona Maria ficar feliz.

Cumpro horário, quando toca o sinal. E dá pra ver o dia da semana, é segunda, terça. Masé automático, é meu jeito. Todo dia eu estou no computador então eu sempre sei que dia é hoje. Eu sei que dia é dia de pagar contas. Hoje é 11. Aí já pagou todas as contas. Eu aviso a esposa, mas ela já sabe. Primeiro as contas, depois pode fazer o que quiser. Não esquece. É porque era eu que gerenciava a casa. 
O que se percebe é que a vivência de Antártica destes homens se vale fortemente da lembrança da família, em particular. Cell (2014), seguindo Husserl, e Ingold (1993), seguindo ambos, relevam a importância do presente na experiência temporal. É somente a partir dele que se concebe qualquer outro momento ou instante, ou, nos termos de Husserl, outro agora. Contudo, o elemento mais importante dos conceitos husserlianos é que as retenções e protensões unem o passado, o presente e o futuro, entre memória e expectativa, não somente numa relação de continuidade, mas também de constante contextualização. $O$ contexto que essa continuidade oferece, permite a sensação de "estar no tempo" (being-in-time), como uma imersão, o que significa a sensação confluente das retenções e protensões que situam o ser e sua noção de realidade. Neste sentido, se de fato o contexto temporal dos marinheiros é frequente e fortemente preenchido por um presente não antártico, o presente destas pessoas tem sua continuidade interrompida ou inclui elementos intrusivos. O relato que menciona telefone e internet, como outros não transcritos aqui, evoca a questão da proximidade virtual entre as pessoas distantes no espaço. De certa forma, a família no Brasil momentaneamente passa a fazer parte do presente antártico dos marinheiros. O que seria puramente retenção e protensão passa a ser também presente efetivo. O fluxo do vivido de Husserl potencialmente se torna muito mais complexo. Se, para Husserl o fluxo entre passado, presente e futuro não é linear, mas uma experiência dinâmica, múltipla e fluida, esta, neste e em casos semelhantes, talvez passe por uma intensificação deste movimento e o fluxo do vivido seja ainda menos linear. Penso que o tempo que se passa na Antártica sujeito a retenções e protensões intensas de lugares e pessoas distantes, seria um construído em parte por um presente em certo "esvaziamento". Contudo, penso que este tempo não se constituiria somente de esvaziamento, visto que há movimentos de intensificação da vivência do presente. A seguir, discute-se como as festividades poderão ser entendidas como geradoras de sociabilidade e intensificação de atividades de modo a preencher o tempo presente.

\section{FESTIVIDADES ANTÁRTICAS: SOCIABILIDADE E INTENSIFICAÇÃO DO PRESENTE}

Para buscar compreender as festas observadas, interessou-me a oposição entre elemento sagrado ou sacralizado (por exemplo, rito de passagem) e elemento profano (por exemplo, comportamento carnal), apontada por Teixeira (2010), criando a oposição entre cerimônia ${ }^{22}$ e festividade. Usando esta dicotomia, participei de dois tipos de festas. No primeiro tipo, o elemento sagrado preponderou (tratou-se de uma cerimônia militar no barco). No segundo tipo de festa, pode-

22 Aqui intitulada cerimônia a celebração poderia também ter sido chamada de ritual ou solenidade. -se dizer que o profano, no sentido de ser mais material e quotidiano, predominou. Deste tipo, participei de uma festividade dos marinheiros-praças (navio), 
uma dos marinheiros-oficiais (navio) e duas integrando ambos (uma em base antártica ${ }^{23}$ e uma em terra, na cidade portuária de Talcahuano, Chile). Descreverei e discutirei brevemente apenas as festividades das quais participaram os praças, levantando algumas possibilidades interpretativas.

As festividades nos barcos são feitas sempre que possível, mas apenas quando este está fundeado, seja na Antártica ou em algum porto, a menos que algum acampamento esteja sendo "lançado". Durante percursos, com o barco em movimento, há um estado de alerta, que gera uma concentração geral nas tarefas a serem desempenhadas, visando o bom funcionamento das fainas ${ }^{24}$. Já quando o barco permanece estático, há menos fainas a serem cumpridas, há menos tensão, há mais tempo livre e o tempo percebido passa mais devagar. Fica evidente, as festas são realizadas quando se tem menos atividades de trabalho, quando se sentiria o tempo passar mais devagar.

Teixeira (2010) coloca que são pontos-chave para compreensão da festa, o seu objeto e o seu modo de celebração. A própria administração do navio estimula festas entre os praças e promove as festas dos oficiais. Podem comemorar aniversários, a chegada a bordo de alguma pessoa de destaque, o sucesso de alguma atividade do navio. Seja qual for o motivo professo da festividade, penso que a fruição, divertimento e alegria são as razões para a realização da festa, promovendo ruptura com o cotidiano e reforçando identidades, no caso, na oposição entre oficiais e praças.

As festividades de mais ampla participação no navio fundeado, festas recorrentes, acontecem nos três espaços designados para relacionamento: praça d'armas (espaço para rancho e convivência dos oficiais), rancho dos sargentos e rancho dos praças (suboficiais). Nelas, são convidados a tripulação (respeitando-se a hierarquia militar) e, quando a bordo, também os pesquisadores (que são como visitantes). $\mathrm{O}$ "outro" no ritual, possivelmente os pesquisadores ou mesmo outras patentes militares, deverá ser melhor estudado, para que a pesquisa não mantenha uniforme a noção, talvez essencialista, de laço social. Por ora, destaca-se que as festividades no navio são realizadas entre os pares e nos espaços destinados à convivência destes entre si. Em outras palavras, as festas dos e para oficiais se dão na praça d'armas, as festas dos e para os praças se dão nos ranchos dos mesmos. Esse ponto chama atenção para a questão identitária e de sociabilidade das festividades. Festeja-se com os seus semelhantes, na hierarquia militar.

Coisa semelhante foi observada em uma festa promovida em 2010, quando o navio já estava atracado no porto de Talcahuano, em comemoração ao primeiro aniversário da compra do navio polar Almirante Maximiano e sua incorporação na frota naval brasileira. Este evento, do qual participaram oficiais, praças e pesquisadores, incluiu uma cerimônia de pronunciamentos (repleta de formalidade e exaltação de orgulho nacional), ainda no início da manhã a bordo do

23 A festa da qual participei na base antártica não será discutida aqui, pois a minha participação foi curta e não se valeu de contexto etnográfico (já as festas nos navios, por sua vez, foram contextualizadas pelo tempo que fiquei embarcada).

24 Os marinheiros usam este termo para referirem-se a tarefas. 
navio, seguidos de um churrasco, com futebol, ping-pong e bolo, já em terra, em espaço alugado, onde pesquisadores, praças e oficiais participaram. Não houve muita mistura de grupos, a não ser no futebol e no ping-pong, e, ocasionalmente, em trânsito na festa. Do contrário, cada grupo sentou-se junto aos seus pares e alguns praças levaram suas acompanhantes chilenas.

De volta ao navio, nas festas dos praças toca-se música alta, pagode às vezes tocado por tripulantes. A escolha da música entre os praças - pagode - e entre os oficiais - música eletrônica dance dos EUA - lembra a discussão bourdieusiana acerca do gosto de classe (Bourdieu, 1983; 2007). O som alto é permitido nos dias das festas, seja dos oficiais como dos praças. São oferecidas comida e bebidas alcoólicas, e a festa atravessa a madrugada. Perez (2002) aponta a festa, baseando-se especialmente em Simmel, em primeiro lugar, como uma experiência social e cultural, marcada pelo lúdico, pelo excesso e pela exaltação dos sentidos e das emoções. Com base em Durkheim, Perez ressal ta o caráter de divertimento, expressão, recreação e estético da festa, tal como seu aspecto teatral e exaltação ou efervescência. Relativos exaltação e exagero são observados nas festas que participei, reservando-se as proporções de tratar-se de um espaço militar (este ponto significante deverá ser melhor elaborado em trabalho subsequente).

É no sentido de que reforçam identidade de grupo e estimulam a fruição que as festas são entendidas aqui como geradoras de sociabilidade. Com base em Durkheim, pode-se pensar que estas reforçam o laço social, reúnem o indivíduo à comunidade, através da experimentação dos sentimentos e reafirmação do grupo (Segalen, 2002). Pensando nestas questões, sugere-se que elas intensificam a vivência do presente. Este ponto ainda merece mais elaboração. Contudo, possível é possível concluir que o tempo que se passa na Antártica se faz de constantes preenchimentos de um presente distante e esvaziamento do presente antártico, pergunto: seria possível compreender estas festas como maneiras de marcar e preencher o presente, potencialmente minimizando os movimentos de retenção e protensão da consciência?

\section{PALAVRAS FINAIS}

Considerando as armadilhas das quais fala Nadel (2010), da utilização de um ou poucos informantes, ressalta-se que não se pretende aqui formar um quadro completo e definitivo sobre a organização e percepção de tempo entre os marinheiros na Antártica. Oferece-se aqui, nos termos do referido antropólogo, uma primeira aproximação ${ }^{25}$. Neste sentido, reconhece-se que este se trata de um tema bastante complexo e que uma etnografia mais intensa será necessária para avançar em muitas das discussões aqui levantadas, tal como para identifi-

25 Reconhece-se aqui o caráter preliminar da pesquisa. Não obstante, isto não significa dizer que se considera o método quantitativo e estatístico proposto por Nardi (2010) ou por Mitchell (2010) como o mais adequado para este caso em específico. 
car quais perguntas seriam relevantes para os marinheiros. Por outro lado, uma pesquisa mais aprofundada poderia minimizar algumas distâncias, tal como uma possível impermeabilidade de uma pesquisadora mulher ${ }^{26}$ em determinados assuntos de um universo prioritariamente masculino que é o dos marinheiros, ou a de acadêmicos em ambiente militar ${ }^{27}$.

Por ora, concluiu-se que o tempo absoluto é consoante com a disciplina militar e se expressa no espaço dos navios e na ordenação das atividades. A dicotomia entre trabalho e lazer é preeminente na cosmologia dos marinheiros, com a preponderância do trabalho face o lazer na organização anual e diária do tempo. Notou-se uma recorrente vontade de que o tempo passe rápido e a sensação de passagem rápida de tempo quanto mais atividades se desempenha, sejam elas de lazer ou trabalho. Além disso, sente-se diferença da velocidade que se percebe o transcorrer do tempo de acordo com as atividades que se desempenha (frente aos grupos de trabalho ou os locais onde o navio está no globo). Neste sentido, o trabalho é bom, no que faz o tempo passar, e ruim, no que os afasta da família. A saudade da família aparece como retenção e protensão, e, por meio de telefonemas e internet, parece evocar um outro presente do qual não participam diretamente ou por completo. Neste sentido, foi sugerido que este fluxo do vivido seja ainda menos linear no caso da Antártica ou viagens atuais mais duradouras.

Algumas destas considerações não são muito distantes do que outros grupos ocidentais contemporâneos vivenciam, dada a natureza intrínseca entre as dicotomias entre trabalho e tempo livre e o próprio sistema econômico, por exemplo. Outras, poderão se referir a viagens extensas como um todo.

Como caminhos de pesquisa futura, aponto que poderá ser interessante acompanhar os vários momentos do ano-calendário, para perceber variações "sazonais", tal como pesquisar sistematicamente os momentos que ladeiam a vivência antártica quando estes são "presente": planejamento ou antecipação e lembrança póstuma da viagem. Por exemplo, interessaria conversar com os marinheiros que já retornaram para casa, para buscar compreender como a lembrança da Antártica se consolida na memória. Ainda, poderá ser interessante estender as conversas a vários representantes de cada grupo de serviço, para ser possível compará-los com mais segurança, da mesma forma que abranger as várias patentes. Outro ponto que merece atenção sistemática é a relação entre os grupos de atividade e os espaços nos quais o navio se encontra (porto, Antártica, Brasil). Também, poderá render frutos estudar as relações de temporalidade na base antártica e nos navios polares, considerando que há mais estabilidade na base antártica, que os marinheiros servem na base durante mais tempo do que nos navios e que os navios estão sempre em trânsito. Ainda, as relações entre tempo livre e tempo de serviço, com relação à percepção da passagem de tempo
26 Silva (2009), ao pesquisar as cadetes da Academia da Força Aérea em São Paulo, notou que o fato de ser mulher e jovem teria ajudado a pesquisa.

27 Nadel (2010) sobre sobre o mito das vantagens inequívocas de se pesquisar a sociedade contemporânea, dados os lugares sociais particulares que se ocupa. 
nas sociedades modernas ocidentais é algo que parece aqui de grande relevância, e que merece ser mais bem explorado. Por fim, como contraponto, poderá ser interessante conversar com outros marinheiros em função naval distinta da polar. Tudo isso poderá auxiliar na discussão acerca do que será exclusivo da experiência antártica de tempo.

\section{AGRADECIMENTOS}

Agradeço aos marinheiros, pelas conversas; ao prof. Andrés Zarankin, pela oportunidade; ao Proantar e ao CNPq, pela logística e financiamento da pesquisa; ao PPCAN-UFMG e ao Leach-UFMG, pelo apoio; ao Igor Rodrigues, pelos comentários à versão final deste artigo.

Sarah de Barros Viana Hissa é cientista social e mestre em Antropologia

(UFMC). Participou de pesquisas acadêmicas sobre história da escravidão, sociologia da arte e arqueologia histórica. No momento, é doutoranda em Arqueologia no Museu Nacional (UFRJ) e atua como arqueóloga no IPHAN.

\section{REFERÊNCIAS BIBLIOGRÁFICAS}

ATASSIO, Aline Prado

2009 "A formação dos praças do exercito". In: CASTRO, C. e LEIRNER, P. (orgs). Antropologia dos militares. Rio de Janeiro, FCV Editora, pp.171-186.

BOURDIEU, Pierre

1984 "Costo de classe e estilo de vida". In: ORTIZ, R.

Pierre Bourdieu. São Paulo, Ática.

2007 A distinção: crítica social do julgamento. São Paulo, Edusp.

CASTRO, Celso

1990 Oespírito militar: um estudo de antropologia social na Academia Militar das Agul has Negras. Rio de Janeiro, Jorge Zahar Editor.

2009 "Antropologia dos militares: reflexões sobre pesquisas de campo". In: CASTRO, C. e LEIRNER, P. (orgs). Antropologia dos militares. Rio de Janeiro, FCV Editora, pp. 13-30. 


\section{CASTRO, Celso e LEIRNER, Piero}

2009 "Por uma antropologia dos militares". In: CASTRO, C. e LEIRNER, P.

(orgs). Antropologia dos militares. Rio de Janeiro, FCV Editora, pp. 7-12.

DIJK, Paul van

2000 Anthropology in the Age of Technology. Atlanta, Editions Rodopi.

EVANS-PRITCHARD, Evans

1978 Os Nuer: uma descrição do modo de subsistência e das instituições

políticas de um povo nilota. São Paulo, Perspectiva.

FABIAN, Johannes

2013 O tempo e o outro: como a antropologia estabelece seu objeto. Petrópolis, Editora Vozes.

FELDMAN-BIANCO, Bela

2010 "Introdução". In: FELDMAN-BIANCO, B. (org.). Antropologia das sociedades contemporâneas. São Paulo, Editora Unesp, pp. 19-56.

GELL, Alfred

2014 Antropologia do tempo: construções culturais de mapas e imagens temporais. Petrópolis, Editora Vozes.

GUIMARÃES, Carlos Magno e MOREIRA, Mariana

2011 "O carvão, o capitalismo e a Antártida (Séc. XIX)". Vestígios: Revista LatinoAmericana de Arqueologia Histórica, Belo Horizonte, v.5. n.2: 87-14.

GROSS, Daniel

1984 "Time Allocation: A Tool for the Study of Cultural Behavior".

Annual Review of Anthropology, Vol. 13: 519-558.

INCOLD, Tim

1993 "The Temporality of the Landscape". World

Archaeology, Vol. 25, No. 2: 152-174.

HISSA, Sarah

2011 "Tempos antárticos: entre momentos, histórias e experiências". Vestígios: Revista latino-americana de arqueologia histórica, v. 5: 53-85.

2012 Tempo e Arqueologia: experiências materiais e imateriais de Antártica. Belo Horizonte, dissertação de mestrado, UFMC. 
HUSSERL, Edmund

2008 A idéia da fenomenologia. Lisboa, Edições 70.

2006 Idéias para uma fenomenologia pura e para uma filosofia fenomenológica. Aparecida, Idéias \& Letras.

1929 Investigaciones lógicas, V.3. Madrid, Revista de Occidente.

1992 Conferências de Paris. LusoSofia Press.

1973 The Phenomenology of Internal Time-Consciousness. Londres, Indiana University Press.

JEFFREY, Bob e TROMAN, Ceoff

2004 "Time for Ethnography". British Educational

Research Journal, v. 30, n. 4: 535-548.

LEIRNER, Piero

2009 "Etnografia com militares: fórmulas, dosagem e posologia".

In: CASTRO, C. e LEIRNER, P. (orgs). Antropologia dos

militares. Rio de Janeiro, FCV Editora, pp: 31-52.

LE GOFF, Jacques

2005 Em busca da Idade Média. Rio de Janeiro, Civilização Brasileira.

LINDER, Staffan Burenstam

1970 The Harried Leisure Class. Nova York, Columbia Univ. Press.

MACNANI, José Guilherme Cantor

1994 Olazerna cidade. São Paulo. Disponível em: http://nau.fflch.usp.br/ sites/nau.fflch.usp.br/files/upload/paginas/lazernacidade.pdf

2003 "A antropologia urbana e os desafios da metrópole". Tempo social USP. São Paulo, pp. 81-98.

MEAD, Margaret

1953 Cultural Patterns and Technical Change. Paris, UNESCO.

NADEL, Stanley

2010 "Compreendendo os povos primitivos". In FELDMAN-

BIANCO, B. (org.). Antropologia das sociedades contemporâneas. São Paulo, Editora Unesp, pp. 59-85. 
PAWSON, Ray

1996 "Theorizing the Interview". The British Journal

of Sociology, v. 47, n. 2: 295-314.

PEREZ, Léa Freitas

2002 "Dionísio nos trópicos: festa religiosa e barroquização do mundo, por uma antropologia das efervescências coletivas". In: PASSOS, Mauro (org.). A festa na vida: significado e imagens. Petrópolis, Editora Vozes, pp. 15-58.

PIETTRE, Bernard

1997 Filosofia e ciência do tempo. Bauru, EDUSC.

RESENDE, Luis Guilherme

2011 "A excepcionalidade da Antártida: notas para pensar antropologicamente". Vestígios: Revista Latino-Americana de Arqueologia Histórica, v.5, n.1:19-59.

RIBEIRO, Gustavo Lins e CROVETTO, Gonzalo Díaz

2011 "O cenário Antártida e seus desdobramentos: considerações voltadas aos estudos da globalização e do transnacionalismo". Vestígios: Revista Latino-Americana de Arqueologia Histórica, v.5, n.1: 09-18.

SANTIBÁÑEZ, Nelson Soto

2011 "La emergencia de las ciudades puerto-puerta em la actividad y dinámica antártica. El caso de Punta Arenas, Chile". Vestígios: Revista Latino-Americana de Arqueologia Histórica, v.5, n.1: 61-93.

SECALEN, Martine

2002 Ritos e rituais contemporâneos. Rio de Janeiro, FCV.

SILVA, Cristina Rodrigues

2009 "Explorando o 'mundo do quartel'. In CASTRO, C. e LEIRNER, P. (orgs). Antropologia dos militares. Rio de Janeiro, FGV Editora, pp. 107-128.

SCHÖPKE, Regina

2009 Matéria em movimento: a ilusão do tempo e o eterno retorno. São Paulo, Martins Fontes.

SOUZA, José et al.

2008 Brasil na Antártica: 25 anos de história. São Carlos, Vento Verde editora. 
STEBBINS, Robert

2001 "The Cost and Benefits of Hedonismo: Some Consequences of Taking Casual Leisure Seriously". Leisure Studies, 20: 305-309.

1982 "Serious Leisure: A Conceptual Statement".

Pacific Sociological Review, 25: 251-272.

TEIXEIRA, Joaquim de Sousa

2010 "Festa e identidade". Comunicação e cultura, n. 10: 17-33.

VALTONEN, Anu

2004 Rethinking Free Time: A Study on Boundaries, Disorder and Symbolic Coods. Helinki, HeSE.

VELHO, Gilberto (org.)

1980 O desafio da cidade: novas perspectivas da antropologia brasileira. Rio de Janeiro, Campus.

VERRILL, Alpheus Hyatt

1916 The Real Story of the Whaler: Whaling, Past and Present. Londres, D. Appleton and Company.

VILLAGRAN, Ximena e SHAEFER, Carlos Ernesto

2011 "Ceoarqueologia das primeiras ocupações humanas na Antártica".

Vestígios: Revista Latino-Americana de Arqueologia Histórica, v.5, n.2: 115-137.

WEBER, Max

2001 A ética protestante e o espírito do capitalismo. São

Paulo, Pioneira Thompson Learing.

ZARANKIN, Andrés; HISSA, Sarah; SALERNO, Melisa; FRONER, YacyAra; RADICCHI, Gerusa; ASSIS, Luis; BATISTA, Anderson.

2011 "Paisagens em branco: arqueologia e antropologia antárticas avanços e desafios". Vestígios: Revista latinoamericana de arqueologia histórica, v. 5, n. 2: 09-51.

ZARANKIN, Andrés e SENATORE, Maria Ximena

2007 Historias de un pasado en Blanco: arqueologia historica antártica. Belo Horizonte, Argumentum. 
Sailing is Needed, Living is Also Needed: First Ideas on Time Organization and Perception of Brazilian Seamen at Antarctica

\section{ABSTRACT}

Scientific Brazilian research in Antarctica is undertaken since 1892, with logistic support from the Brazilian Navy. After a relatively brief ethnographic field work in polar ships, we intend to discuss how seamen perceive time and its passage. Three factors were mainly considered: the activities undertaken; retention and protention conscience movements; and festivities. It was noted a desire from the sailors for time to pass quickly, and that the intensification of leisure or work activities offer a sensation of a quick passage of time. The memory of home is constantly present, suggesting a partial presence in that space, were other places and moments are invited to inhabit Antartica. In this contexts, festivities may mean, for the sailors, a way to intensify the present.

Recebido em 10 de setembro de 2014. Aceito em 4 de maio de 2017.

\section{KEYWORDS}

Antarctica, Time, Sailor, Seasonality, Space 